\title{
Attenuations of bacterial spot disease Xanthomonas euvesicatoria on tomato plants treated with biostimulants
}

\author{
Aminthia Pombo Sudré da Silva' ${ }^{1}$ Fábio Lopes Olivares ${ }^{1}$, Cláudia Pombo Sudré2, \\ Lázaro Eustáquio Pereira Peres ${ }^{3}$, Natália Aguiar Canellas ${ }^{1}$, Rakiely Martins da Silva' ${ }^{1}$ Vicenza Cozzolino ${ }^{4}$ and \\ Luciano Pasqualoto Canellas ${ }^{1 *}$ (D)
}

\begin{abstract}
Background: The bacterial-spot disease caused by different Xanthomonas species is one of the major tomato diseases that reduce crop production and quality. Pesticides indiscriminate usage has resulted in an increase in resistant bacterial strains as well as contamination of farmers, consumers and the environment. Plant growth-promoting bacteria and humic acids can act as elicitors of plant defence mechanism causing extensive transcriptional and metabolic reprogramming which, in turn, produce a range of plant chemical defences. The purpose of this study was to study how humic acids and plant growth-promoting bacteria, when applied to the substrate, affected the severity of bacterial spot symptoms in tomato leaves.
\end{abstract}

Materials and methods: One-month-old Micro-Tom tomato (Solanum lycopersicum L.) were transferred to $3 \mathrm{~L}$ pots filled with a sterile mixture of sand and vermiculite $(2: 1, \mathrm{v}: \mathrm{v})$ and treated or not (control) with $250 \mathrm{~mL}$ of $4.5 \mathrm{mmol} \mathrm{C}$. $\mathrm{L}^{-1}$ of humic acids, Herbaspirillum seropedicae $\left(10^{8} \mathrm{CFU} . \mathrm{mL}^{-1}\right)$ and the combination of humic acids plus H. seropedicae. One day after substrate treatment, the leaves were inoculated (or not) with X. euvesicatoria (Xe). The area below the disease progression curve based on severity scores and the number of symptomatic leaflets was used to assess phytopathogen virulence. The concentration of oxalic, citric and succinic acids in leaf extracts were determined using HPLC analysis.

Results: Sole or combined H. seropedicae (BAC) and humic acids (HA) application promoted shoot and root growth related to control when plants were challenged with Xe pathogen. For plants inoculated with Xe, more significant plant-growth promotion results were obtained for $\mathrm{HA}+\mathrm{BAC}$ treatment. The first visible symptoms were observed 16 days after inoculation with $2 \times 10^{4} \mathrm{CFU} . \mathrm{g}^{-1}$ of Xe cells in leaves of control plants. HA and BAC applied alone or combined reduced disease severity. Only plants treated with HA were able to reduce disease incidence (number of the leaflets with symptoms). Organic acids, such as oxalic, citric and succinic acids, rose in Xe-inoculated leaves. The reduced amount of organic acids in diseased leaves treated with HA + BAC may be linked to a decrease in disease progression.

\footnotetext{
*Correspondence: lucianocanellas@gmail.com

${ }^{1}$ Núcleo de Desenvolvimento de Insumos Biológicos Para a Agricultura

(NUDIBA), Universidade Estadual do Norte Fluminense Darcy Ribeiro,

Avenida Alberto Lamego No. 2000, Rio de Janeiro, Campos dos

Goytacazes CEP 28013-602, Brazil

Full list of author information is available at the end of the article
} original author(s) and the source, provide a link to the Creative Commons licence, and indicate if changes were made. The images or other third party material in this article are included in the article's Creative Commons licence, unless indicated otherwise in a credit line to the material. If material is not included in the article's Creative Commons licence and your intended use is not permitted by statutory regulation or exceeds the permitted use, you will need to obtain permission directly from the copyright holder. To view a copy of this licence, visit http://creativecommons.org/licenses/by/4.0/. The Creative Commons Public Domain Dedication waiver (http://creativeco mmons.org/publicdomain/zero/1.0/) applies to the data made available in this article, unless otherwise stated in a credit line to the data. 
Conclusion: Humic acids and $\mathrm{H}$. seropedicae increased growth by modulating the content of organic acids in leaf tissue, attenuating the symptoms of the bacterial spot disease.

Keywords: Biocontrol, Systemic resistance, Plant-growth promotion, Humic substances, Endophytic bacteria

\section{Introduction}

Biofertilization with soluble humates and plant growthpromoting bacteria has attracted attention in recent years due to its beneficial effects on nutrient uptake and protection of plants against abiotic stress $[1,2]$. This protection is generally due to increase of enzymatic and nonenzymatic antioxidant defenses, increase in compatible solutes production and changes in ion balance as well as boost in metabolism and plant growth. However, studies on the role of humates in mitigating plant diseases are very scarce [3]. Studies using stable organic matter applied to fungal diseases suppression have been widely reported [4-10]. Our group recently evaluated the concept of substrate biofertilization using humates and plant growth-promoting bacteria to produce vigorous tomato seedlings and, after field transplantation, showed higher crop yield [11]. The additional foliar application of humic acids combined with plant growth-promoting bacteria resulted in a lower incidence of Phytophthora infestans [11].

São José de Ubá is located in the northwest of the Rio de Janeiro state (Brazil), a region with one of the largest tomato producers in the Rio de Janeiro state. The diagnoses for pesticides use by tomato farmers showed that a mixture of different products is indiscriminately used without requirement, not respecting pre harvest interval (PHI) or waiting period, lacking technical assistance during all cultivation cycle and without using personal protective equipment [12,13]. There are no products to control bacterial diseases, and farmers with fear of losing their production use many products prohibited or unlicensed in an attempt to preserve the harvest. The main bacterial disease in tomatoes in this region is caused by Xanthomonas euvesicatoria promoting loss in fruit productivity and quality due to the yellowing of the leaves, followed by defoliation, reducing the photosynthetic area and exposing the fruits to the sun, which can cause scalding in them. The control is difficult, and some chemical products are prohibited in other countries, because it is highly dangerous, and many microorganisms become resistant to chemical control [14].

Systemic acquired resistance (SAR) and induced systemic resistance (ISR) are two forms of induced resistance, wherein plant defences are preconditioned by prior infection or treatment that results in resistance against subsequent challenge by a pathogen [3]. The SAR is characterised by proteins related to pathogen (PR-proteins) and can change the plant morphology and anatomy and use salicylate as cell signalling. Differently, ISR did not show PR-protein accumulation and used other signalling pathways, such as ethylene and jasmonates with low plant morphology changes [15-17]. Plant growthpromoting bacteria can trigger the salicylic acid (SA)dependent SAR and SA-independent ISR pathway [18]. Humic substances can increase the concentration of phenolic compounds [19] and peroxidase activity [20], as well as phenylalanine ammonia-lyase (PAL) activity [21] in leaves tissues. PAL is the key enzyme involved in synthesising phenolics and lignin compounds via the phenylpropanoid pathway.

Composts and water extracts could be used to induce plant resistance [22]. Dahmani et al. [23] investigated the efficacy of foliar sprays with compost water extracts in reducing the severity of bacterial spot of tomato caused by Xanthomonas euvesicatoria and observed decrease the bacterial spot disease damage in tomato, increasing fruit yield. These previous results indicate the possibility of natural products to reduce the plant diseases severity and, if not eliminate, at least reduce the toxic and lethal load of pesticides commonly applied to tomatoes. Herbaspirillum seropedicae is an endophytic diazotroph and forms nitrogen-fixing associations with several economically important crops in the family Poaceae, such as maize, rice, sorghum, and sugarcane, and can increase their growth and productivity by a number of mechanisms, besides nitrogen fixation, including the induction of systemic resistance to pathogens [24].

This work aimed to induce the systemic resistance of tomato against bacterial spot using humic acids isolated from vermicompost and $H$. seropedicae applied separately or in combination directly on the plant growth substrate.

\section{Materials and methods \\ Plant assay}

The sowing of the 'Micro-Tom' tomato (Solanum lycopersicum L.) seeds was carried out in 128-cell polystyrene trays with Vivatto ${ }^{\circledR}$ commercial substrate irrigated once a day. They were kept in a growth chamber at $28{ }^{\circ} \mathrm{C}$ and $80 \%$ relative humidity with a photoperiod of $16 \mathrm{~h}$ day and $8 \mathrm{~h}$ night. Thirty days after sowing, the seedlings were transplanted into $3 \mathrm{~L}$ pots in a greenhouse filled with sand: vermiculite mixture $(2: 1 \mathrm{ratio}, \mathrm{v} / \mathrm{v})$. This substrate 
was autoclaved three times at $121^{\circ} \mathrm{C}, 1 \mathrm{~atm}$ for $1 \mathrm{~h}$ before pot filling.

\section{Inoculum production}

The inoculum of Herbaspirillum seropedicae strain HRC54, was obtained at the Laboratório de Biologia Celular e Tecidual (LBCT/UENF). The bacteria were grown in DYGS liquid medium (Dextrose Yeast Glucose Sucrose) under rotation of $120 \mathrm{rpm}$ at $30^{\circ} \mathrm{C}$ for $24 \mathrm{~h}$. The bacterial suspension was adjusted to $10^{8} \mathrm{CFU} \mathrm{mL}^{-1}$ [25]. The inoculum of Xanthomonas euvesicatoria T1P3 [26] was prepared from the ENA 4135 isolate, provided by the Departamento de Fitopatologia da Universidade Federal de Lavras (UFLA), Brazil. This isolate was selected for its pathogenicity, which was previously tested [27] and resistance to copper-based pesticides. The isolate was grown in DYGS liquid medium for approximately $36 \mathrm{~h}$, under agitation $(100 \mathrm{rpm})$ at $28{ }^{\circ} \mathrm{C}$. Then, the bacteria were cultured in Petri dishes containing the solid DYGS medium. After $36 \mathrm{~h}$ of growth, at $28^{\circ} \mathrm{C}$, the bacterial colonies were suspended in sterile water, and the cell concentration was adjusted to $10^{8} \mathrm{CFU} . \mathrm{mL}^{-1}$ by visible spectrophotometry at $600 \mathrm{~nm}$.

\section{Humic acids extraction}

Humic substances were extracted from vermicompost produced with sugarcane filter cake and $E$. Andrei with $0.1 \mathrm{~mol} \mathrm{~L}^{-1} \mathrm{NaOH}$ 1:10 (v:v), under an atmosphere of $\mathrm{N}_{2}$ for $4 \mathrm{~h}$ followed by centrifugation $(3000 \times g)$. The separation of humic acids from the alkaline extract was obtained by acidification at pH 1 with $6 \mathrm{~mol} \mathrm{~L}^{-1} \mathrm{HCl}$. Dissolution and precipitation were repeated three times. After centrifugation, the HA fraction was washed with water until there was a negative test with $\mathrm{AgNO}_{3}$ titrate until pH 7.00 with $\mathrm{NaOH} 0.01 \mathrm{~mol} \mathrm{~L}^{-1}$ and dialysed (molecular mass cutoff $1 \mathrm{kDa}$; Spectrapor, USA) and freeze-dried. The carbon content of the HA was measured using a
CHN analyser (Perkin-Elmer 1483; Perkin-Elmer, Norwalk, CT, USA). The HA suspension was prepared dissolved $106 \mathrm{mg} \mathrm{HA}$ in $1 \mathrm{~L}$ of $\mathrm{CaCl}_{2} 2 \mathrm{mmol} \mathrm{L}^{-1}$. The $\mathrm{pH}$ was adjusted to $5.8 \pm 0,1$.

\section{Evaluation of bacterial strain resistance}

The experiment to evaluate resistance to bacterial strain was conducted in a greenhouse. The experimental design was entirely random, in a $4 \times 2$ factorial scheme using four treatments in the substrate $\left(\mathrm{CaCl}_{2} 2 \mathrm{mmol}\right.$. $\mathrm{L}^{-1}$-as a control; H. seropedicae $10^{8}$ UFC. $\mathrm{mL}^{-1}-\mathrm{BAC}$; Humic acids at $4.5 \mathrm{mmol} \mathrm{C.} \mathrm{L}^{-1}-\mathrm{HA} ;$ H. seropedicae + Humic acids-HA + BAC), and two treatments (without and with $X$. euvesicatoria inoculation) applied on leaves. Ten replicates and one plant per pot were used. One day after transplantation, treatments were applied in the substrate using $250 \mathrm{~mL}$ of control; HA; BAC; HA + BAC). HA and bacterial suspension were prepared as described above but placed in the proportion of 4 HA: 1 BAC (v:v). The plants were irrigated with water, but 2 days a week were irrigated with Clark's nutrient solution, in which in the first week it was with $1 / 4$ concentration, in the second week with $1 / 2$ in the third $3 / 4$ and from the fourth week complete concentration. The inoculation of the bacterial suspension of $X$. euvesicatoria occurred 21 days after applying treatments (56 days after sowing). Applying in half of each treatment pots (5 pots) by spraying on the leaves and water was used in control. After X. euvesicatoria inoculation, a humid chamber $>90 \%$ relative humidity was performed using plastic bags. After $72 \mathrm{~h}$ in a humid chamber, the bags were removed, and observations of the disease's symptoms (severity and number of infected leaflets) began. The evaluations were carried out on alternate days in a total of seven evaluations of resistance to bacterial spot (X. euvesicatoria-Xe) based on a severity scale using notes adapted from Mello et al. [28] according to Fig. 1.

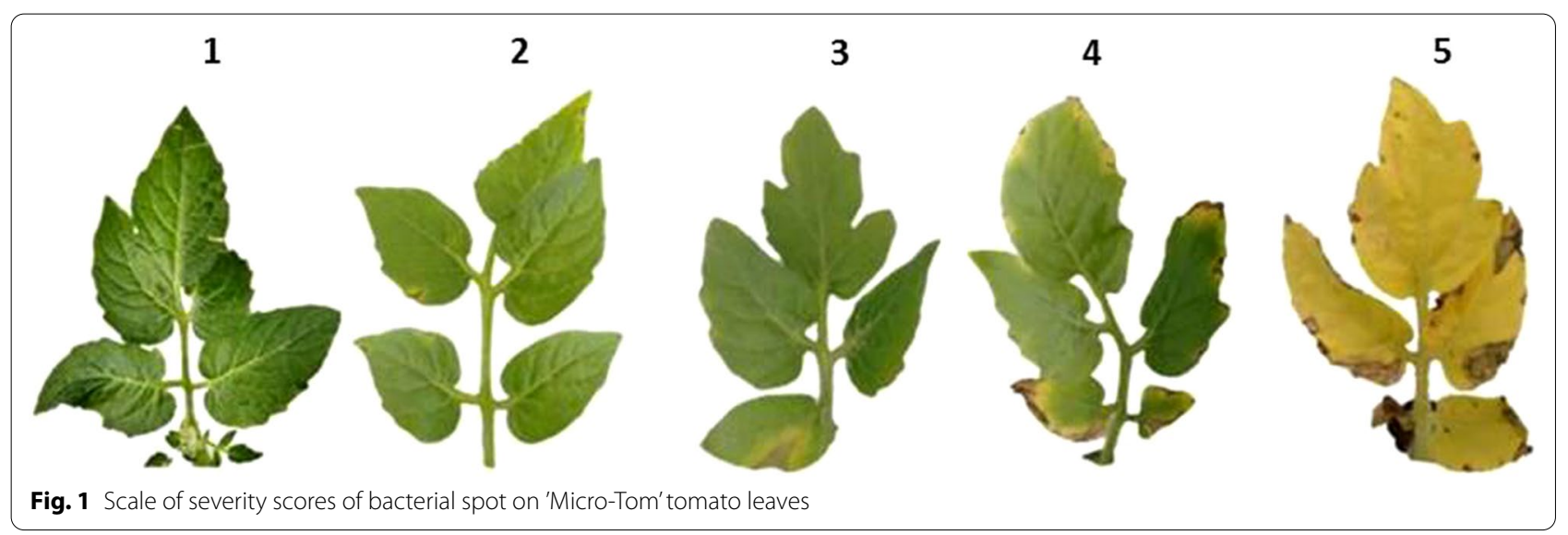


Using the notes of severity and number of leaflets, the area under the disease progress curve (AUDPC) was calculated, in which the data obtained were integrated and calculated using the following equation: AUDPC $=\sum[(y 1+y 2) / 2] *(t 2-t 1)$, where $y 1$ and $y 2$ refer to two successive assessments of disease intensity performed at times $t 1$ and $t 2$, respectively [28].

The plants harvested occurred 21 days after the inoculation of the pathogen. The plants were divided into two parts, leaves and root. The collected roots were washed until the substrate was completely removed and washed once more in distilled water. Subsequently, the fresh mass was determined, and the dry mass was obtained after drying at $60{ }^{\circ} \mathrm{C}$ to be subsequently used for extraction of organic acids analysed in HPLC. The AUDPC data of the plants inoculated with $X$. euvesicatoria and the mass data were subjected to analysis of variance and means comparison test (Tukey's test) at a level of 5\% probability using the SAEG statistical program.

\section{Identification and quantification of organic acids on HPLC}

The analysis of organic acids was performed by high-performance liquid chromatography (HPLC) for the leaves previously dried at $\pm 60{ }^{\circ} \mathrm{C}$. $0.250 \pm 0.001 \mathrm{~g}$ were mixed with $3.5 \mathrm{~mL}$ methanol: acetic acid 85:15 (v/ v) and macerated in the porcelain mortar until it acquires liquid consistency, as homogeneous as possible. The extract obtained was transferred to a beaker and remained in the ultrasound for $30 \mathrm{~min}$. The final volume was adjusted to $5 \mathrm{~mL}$ of solution with ultra-pure water. This diluted extract was centrifuged at $100 \mathrm{rpm}$ at $25{ }^{\circ} \mathrm{C}$ for $5 \mathrm{~min}$. Organic acids were identified and quantified by HPLC using a Younglin Instrument chromatograph, with a
$210 \mathrm{~nm}$ wavelength UV detector, using a REZEX ROAOrganic acid $\mathrm{H}^{+}$column $(300 \times 7,8 \mathrm{~mm})$. The injected volume of the sample was $20 \mu \mathrm{L} .280 \mu \mathrm{L}$ of sulfuric acid/L (2.4 mmol sulfuric acid/L) was used as the mobile phase, with a flow rate of $0.6 \mathrm{~mL} / \mathrm{min}$. It is carried out at room temperature. The peaks corresponding to each acid were identified by the retention time, using the standards' retention times as a comparison. The data obtained were subjected to analysis of variance (ANOVA), and the statistical differences were determined using the DMSt means comparison test (Tukey's test) at a significance level of $5 \%$. The concentration obtained was expressed in $\mathrm{mg} \mathrm{L}^{-1}$ of organic acid.

\section{Results}

We evaluated the population size of $H$. seropedicae cells established in the plant growth substrate using the most probable number (MPN) methodology at 5 and 15 days after suspension application. We found 1.3 and $1.5 \times 10^{5}$ CFU. $\mathrm{mL}^{-1}$ for BAC treatment and 2.0 and $2.5 \times 10^{4}$ CFU. $\mathrm{mL}^{-1}$ for $\mathrm{HA}+\mathrm{BAC}$ treatment. As expected, $H$. seropedicae was not detected in the control and HA treatment (data not shown). When $X$. euvesicatoria was inoculated in leaves, $H$. seropedicae population number was increased in $\mathrm{BAC}$ and $\mathrm{BAC}+\mathrm{AH}$ treated substrate.

The virulence of the $X$. euvesicatoria ENA 4135 isolate used to inoculate the tomato was attested by the characteristic symptoms of the bacterial spot disease observed in treated plants: necrotic spots with yellow halos, mainly from the border to the centre of the leaf, and the presence of anticipated senescence of older leaves with a greater symptomatic area (Fig. 2).
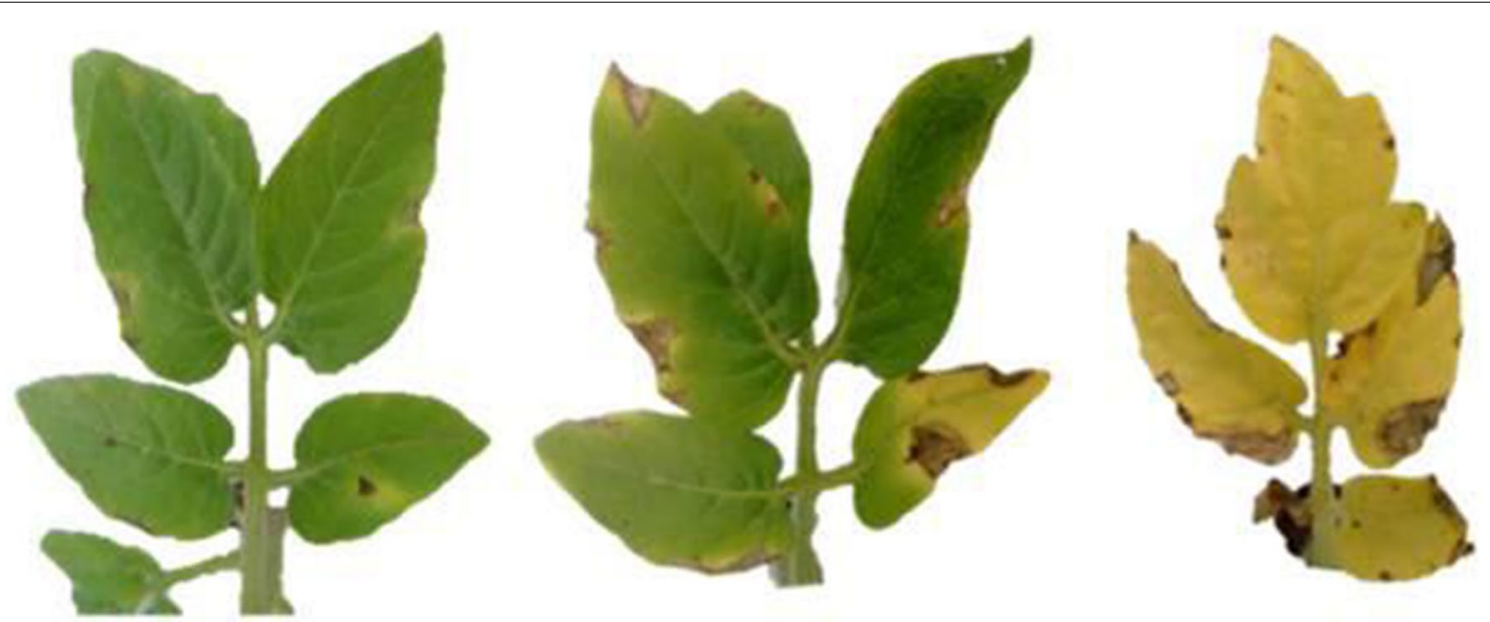

Fig. 2 Symptoms of bacterial spot disease on 'Micro-Tom' tomato leaves inoculated with Xanthomonas euvesicatoria T1P3: necrotic spots (left) with yellowish edges (middle) and generalised yellowing indicating pre-senescence (right) 
The fresh weight of leaves and root tissues treated or not (control) with humic acids (HA) and $H$. seropedicae (BAC) in the presence or not of Xanthomonas euvesicatoria are shown in Fig. 3. The presence of pathogen decreased both leaf and root fresh weight. However, the treatment with $\mathrm{HA}+\mathrm{BAC}$ increased the leaf and root weight in the plants inoculated with $X$. euvesicatoria $(X e)$, compared to non-biostimulated plants without $X e$ (Fig. 3), probably due to a synergistic plant-growth stimulation by both HA and BAC. The HA-treated plants enhanced the roots fresh weight 1.5 fold compared to control in the absence of the pathogen. The lowest root fresh weight was found in the $H$. seropedicae treatment in the pathogen's presence on the leaves. However, the substrate treatment $\mathrm{HA}+\mathrm{BAC}$ showed a significant increase of root fresh weight in plants inoculated with the pathogen (Fig. 3B).

It was noticed that in some treatments, the symptoms of bacterial spot started at the edges, with small spots that did not progress but entered the count of symptomatic leaflets. Despite the absence of statistical difference for disease incidence, a significant reduction for AUCDP severity was noticed for all treatments related to control (Fig. 4A). The severity of the bacterial spot disease was reduced around $50 \%$ by the substrate treatment with HA and $H$. seropedicae.

The control with pathogen inoculation received a higher severity score on the last day of the assessment. HA-treatment obtained the lowest AUCPD value for the number of leaflets on the last day of evaluation (Fig. 4B). The incubation period for Xe was 8 days for the control and HA, 10 and 11 days for BAC and $\mathrm{AH}+\mathrm{BAC}$, respectively. We noticed that the longer the time for first symptoms to appear, the less aggressive is the disease.

The concentrations of oxalic, citric and succinic acids in the leaves extracts with and without X. euvesicatoria are shown in Table 1 . The concentration of oxalic acids in control inoculated with $X$. euvesicatoria was $67 \%$ higher than the plant treated with HA and inoculated with $X$. euvesicatoria. However, we noticed that HA treatment had different characteristics, compared to control plants inoculated with $X$. euvesicatoria, showing a rapid infection, but this severity found in the initial evaluation days did not increase. On the last day of evaluation, HA treatment presented a smaller area under the disease progress curve (AUDPC) among treatments (Fig. 4B). Oxalic acid has previously been linked to senescence and programmed cell death [29]. The rapid senescence was observed in control with $X$. euvesicatoria and the leaves yellowing, indicating greater severity of the disease due to the greater infected leaf area (greater necrotic area). The concentration of the applied pathogen was $10^{8} \mathrm{CFU} / \mathrm{mL}$, which is considered very high. Plants no infected with $X$. euvesicatoria showed similar content of citric and succinic acids in leaves among treatments (Table 1). The HA + BAC significantly increase the content of citric acid in plants infected with $X$. euvesicatoria, while the succinic acid was found in larger content in control plants.
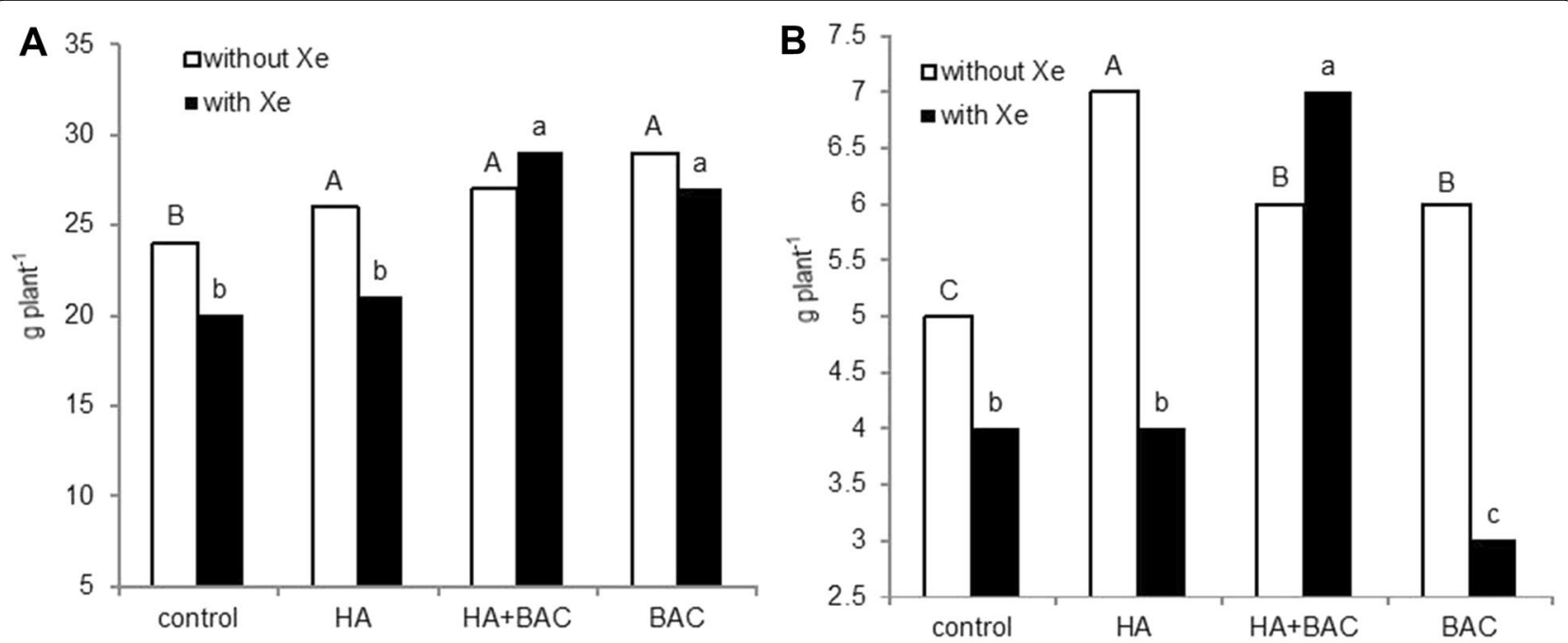

Fig. 3 Leaves $(\mathbf{A})$ and roots $(\mathbf{B})$ fresh weight of tomato plants grown on substrate treated or not (control) with humic acids (HA), $H$. seropedicae $(B A C)$ and the combination of both ( $\mathrm{HA}+\mathrm{BAC})$. White and black bars represent treatments without and with Xanthomomas euvesicatoria (Xe), respectively. Means followed by the same capital letters (without Xe) or followed by the same small letters (with Xe) do not differ by the Tukey's test, $p<0.05$ 

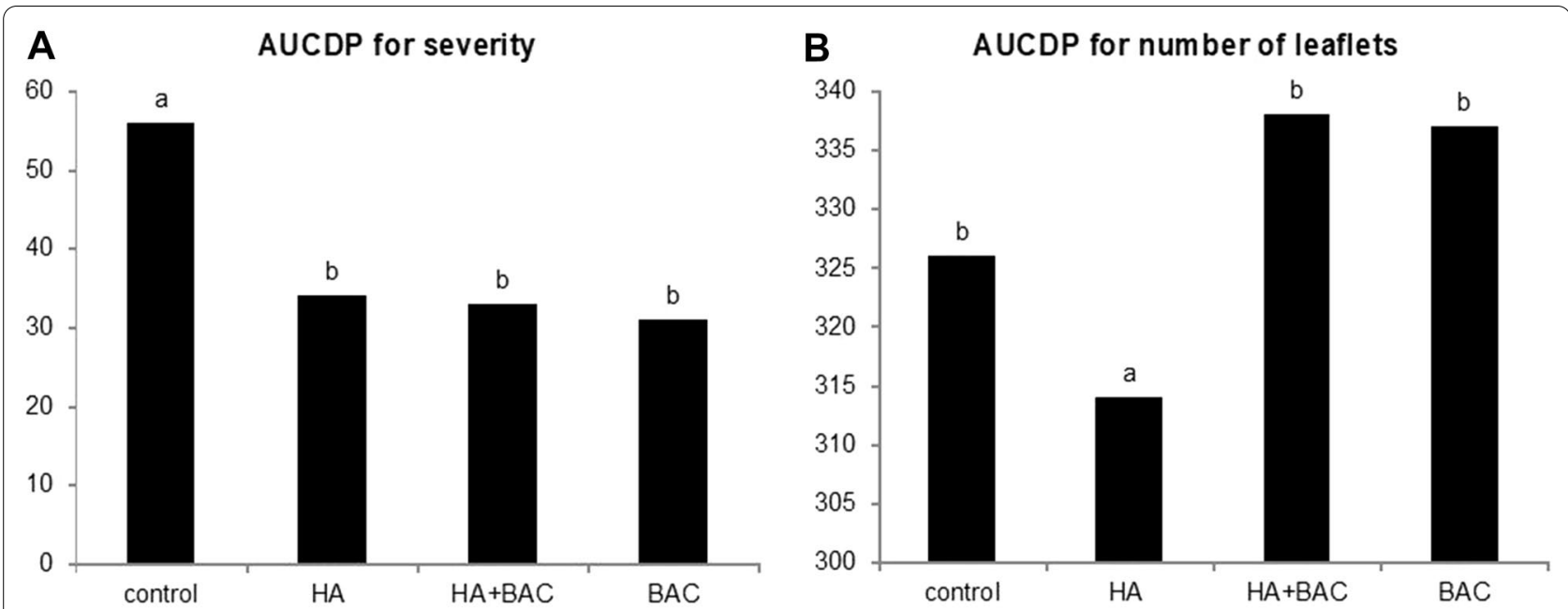

Fig. 4 Area below the disease progress curve (AUCDP) for the severity of bacterial spot disease in 'Micro-Tom' tomatoes (A) and the number of leaflets (B) as affected by HA: humic acids; BAC: Herbspirillum seropedicae; Means followed by the same letters do not differ by the Tukey's test, $p<0.05$

Table. 1 Concentration of oxalic, citric and succinic acids (mg $\mathrm{kg}^{-1}$ ) in leaves extracts from MT Tomato growth in the substrate treated with humic acids (HA), Herbaspirillum seropedicae (BAC) and in combination (HA +BAC) after inoculation or not of Xanthomonas euvesicatoria on the leaves

\begin{tabular}{|c|c|c|}
\hline & Without $X$. euvesicatoria & With $X$. euvesicatoria \\
\hline & Oxalic acid & \\
\hline Control & $776( \pm 103) \mathrm{Aa}$ & $1426( \pm 1382) \mathrm{A} \mathrm{a}$ \\
\hline HA & nd & $944( \pm 208) \mathrm{A} \mathrm{a}$ \\
\hline BAC & $458( \pm 648) \mathrm{A} \mathrm{a}$ & $563( \pm 538) \mathrm{A} \mathrm{a}$ \\
\hline \multirow[t]{2}{*}{$\mathrm{HA}+\mathrm{BAC}$} & nd & $700( \pm 990) \mathrm{A} \mathrm{a}$ \\
\hline & Citric acid & \\
\hline Control & $456( \pm 188) \mathrm{Aa}$ & $1169( \pm 319) \mathrm{BC}$ a \\
\hline HA & $748( \pm 258) \mathrm{A} \mathrm{a}$ & $1593( \pm 1375) \mathrm{AB}$ a \\
\hline BAC & $547( \pm 92) \mathrm{A} \mathrm{a}$ & $720( \pm 398) A B$ a \\
\hline \multirow[t]{2}{*}{$\mathrm{HA}+\mathrm{BAC}$} & $612( \pm 327) \mathrm{Ab}$ & $2244( \pm 1115) \mathrm{Ca}$ \\
\hline & Succinic acid & \\
\hline Control & $74( \pm 0.1) A b$ & $220( \pm 129) \mathrm{A} \mathrm{a}$ \\
\hline HA & $79( \pm 11) \mathrm{A} \mathrm{a}$ & $131( \pm 2) \mathrm{B} \mathrm{a}$ \\
\hline BAC & $84( \pm 24) \mathrm{A} \mathrm{a}$ & $75( \pm 49) \mathrm{B} \mathrm{a}$ \\
\hline $\mathrm{HA}+\mathrm{BAC}$ & $93( \pm 2) \mathrm{Aa}$ & $120( \pm 50) \mathrm{B} \mathrm{a}$ \\
\hline
\end{tabular}

${ }^{1}$ Means \pm standard deviation followed by same capitals letters in the column and lowercase in the lines are not different by Tukey test. nd not detected in the four repetitions

\section{Discussion}

Humic acids and plant growth-promoting bacteria can reduce the use of pesticides and fertilisers, significantly cutting down on the costs of production and promoting farmers and consumers' health. The potentiality of vermicompost extracts as bio-control agents has been recognised [30]. The foliar application of aqueous vermicompost extracts is suggested to be utilised by the farmers as an easy, cheap, and efficient system of crop protection with high-yielding capacity [31].

Plant growth-promoting bacteria can elicit plant defence mechanisms consisting of an eco-friendly strategy to reduce pesticides and it is widely used in some crops [3]. Beneficial associations of $H$. seropedicae with sorghum, sugar cane, rice, and maize have been reported but some isolates can causes red stripe disease on some sorghum varieties and can cause mottled stripe disease on sugarcane and induced disease symptoms in rice [32]. The response of the host plant to $H$. seropedicaes includes both the recognition of the bacteria as non-pathogenic and the induction of systemic resistance to pathogens $[24,32]$.

The fact that organic matter and its fractions also elicit plant defence responses is less recognised, despite previous evidence $[21,23,30]$. Here we reported the results obtained with direct application of $\mathrm{HA}$ and BAC on the substrate aiming to attenuate the symptoms of bacterial spot on tomatoes leaves. The substrate treated with biostimulants and further inoculation of leaves with Xanthomonas euvesicatoria resulted in fewer symptoms of bacterial spot. Previous reports showed that humic substances and aqueous extracts of composts and vermicomposts can suppress fungal and bacterial diseases, such as Pythium, Rhizoctonia, and Plectosporium, Fusarium and Verticillium [4-10]. Studies considering plant-bacterial disease control by humic substances are scarce. Al-Damahy et al. [23] showed the possibility of suppressing bacterial spot of tomato with 
foliar sprays of compost extracts. They reported a moderate but statistically significant reduction in the severity of bacterial spot in the greenhouse bioassays and ineffective in the field against the disease's foliar phase. The mechanisms in which aqueous extracts of compost suppress the plant bacterial disease are still speculative. The use of HA on the substrate promoted the reduction of bacterial spot severity (Fig. 4), indirectly indicating the occurrence of ISR mechanism. In line with this, compost amendments into soil decreased the disease severity of some aboveground diseases in tomatoes [21].

Several biochemical and physiological changes have been associated with pathogen infection, including cell death and oxidative burst, deposition of callose and lignin, and the synthesis of phytoalexins and novel proteins [33]. The main characteristics of SAR mechanism are the production of $\mathrm{PR}$ proteins mediated by the salicylic acid (SA) pathway. We found no reports showing direct evidence that humic substances could promote differential gene expression encoding PR; however, the conversion of phenylalanine to trans-cinnamic acid catalysed by PAL is part of the SA biosynthetic pathway. The conversion of trans-cinnamic acid into SA has been proposed to proceed via chain shortening to produce benzoic acid, followed by hydroxylation at the $\mathrm{C}-2$ position to derive SA [33]. The last step is likely catalysed by a cytochrome P450 monooxygenase, called benzoic acid 2-hydroxylase. Both PAL and P450 monooxygenase were found in a high transcription level in plants treated with HA [19, 33]. The larger concentration of SA, benzoic and cinnamic acids were found in leaves tissues in plants treated with $\mathrm{HA}$ and $\mathrm{HA}+\mathrm{BAC}[35,36]$. The presence of phenolics compounds and their oxidation products in the plant tissue is toxic to pathogen growth. Different types of plant biostimulants, including humic substance, enhanced phenolics content in plants [37].

Moreover, Nunes et al. [38] showed that HA could increase several antioxidant enzymes, among them 2-Cys peroxiredoxin BAS1, a putative heat shock protein 90 family protein, glutathione peroxidase and PAL. Heat shock proteins are found ubiquitously in plant and animal cells and are involved in heat shock and a wide variety of stresses, including biotic stresses [39]. In addition, HA triggers expressions of heat shock proteins both in the absence and presence of heat stress [40].

The proteomic analysis showing the promotion of several antioxidant enzymatic activities [39] can be associated with SAR mechanisms triggered by humic substances. Superoxide dismutase (SOD) and catalase are antioxidants involved in oxygen radical scavenging that play a critical role in determining the consequences of plant-pathogen interactions [41]. The promotion of SOD and CAT activities in leaf extracts of sugarcane treated with HA were previously observed [42].

Induced systemic resistance (ISR) does not produce PR and is mediated by a jasmonate/ethylene sensitive pathway for cell signalling and emerged as an important mechanism by which selected plant growth-promoting bacteria and other agents prime the whole plant body for defence against a broad range of pathogens and insect herbivore [3]. Some previous evidences that humic substances can act as a prime chemical agent and that compost and vermicompost-amended soils might improve plant defence were reported [21, 23, 34]. In addition, it was previously reported that HA could enhance the content of jasmonic acid (JA) and its derivatives [43-45], including JA conjugate with isoleucine (JA-Ile), the most bioactive form. De Hita et al. [44] observed a large SA concentration in roots when HA was applied on leaves. Unfortunately, the authors did not measure or present the leaves' JA concentration values when HA was applied only to the roots [42]. Moreover, it was previously indicated that JA and methyl-JA could regulate the ascorbate-glutathione cycle, two crucial nonenzymatic compounds involved in defence against oxidative stress [46]. The larger concentration of ascorbate in plants treated with HA and $H$. seropedicae and their combination was previously reported in a plant metabolome study [33], and the high level of proteins involved in the ascorbate-glutathione cycle was also reported [38].

Finally, it is well known that the pathogen's presence increases the concentration of organic acids [29], which is also evidenced here by the larger organic acids concentration in the tomatoes inoculated with $X$. euvesicatoria (Table 1). All the treatments (HA, BAC and $\mathrm{HA}+\mathrm{BAC}$ ) decreased the concentration of the organic acids. The oxidative burst, defined as controlled release of $\mathrm{O}_{2}$ and $\mathrm{H}_{2} \mathrm{O}_{2}$, is one of the earliest and universal responses observed in plants following pathogen challenge [29]. The oxidative burst is also known to be suppressed at low cell $\mathrm{pH}$ [46]. Humic acids, such as short-chain organic acids, decrease the intracellular $\mathrm{pH}$ showed by the increased fluorescence of BCECF probe ((2,7-bis(2-carboxyethyl)5(and 6)-carboxyfluorescein, acetoxymethyl ester) and can act directly avoiding the oxidative burst [47].

\section{Conclusion}

Bacterial spot of tomato, caused by $X$. euvesicatoria, is a serious problem of tomatoes in North of Rio de Janeiro, Brazil. Once the disease is established in a crop, currently available management strategies are only partially effective and farmers indiscriminately use a cocktail of pesticides that are harmful to health and the environment. Plants are able to mount a number of defense responses upon pathogen attack. Induced resistance is a state of 
enhanced defensive capacity developed by a plant when appropriately stimulated. Humic acids and $H$. seropedicae when applied to growth medium acting as abiotic and biotic elicitors triggering defense mechanisms prior to infection by $X$. euvesicatoria reducing the symptoms in the leaves. The biostimulant based on humic acids and $H$. seropedicae reduced foliar disease severity and the incidence of bacterial spot.

\section{Abbreviations \\ HA: Humic acids isolated from vermicompost; BAC: Herbaspirillum seropedi- cae; HA + BAC: Suspension with HA plus BAC.}

\section{Acknowledgements}

We thank the annonimous referees for helping us improve the manuscript.

\section{Authors' contributions}

APSS carried out the experiments; CPS was responsible by $X$. euvesicatoria inoculum and supervised the greenhouse experiment; RMS and VC reviewed the scientific literature and supervised the data analysis; NAC developed the HPLC method and supervised the analysis. LPC, CPS, FLO and LEPP conceived the experimental idea, designed the experiment and were responsible for writing the manuscript. All authors read and approved the final manuscript.

\section{Funding}

This work was supported by Fundação Carlos Chagas Filho de Amparo à Pesquisa do Estado do Rio de Janeiro (FAPERJ) Cientista do Nosso Estado programm, Conselho Nacional de Desenvolvimento de Pesquisa e Tecnologia (CNPq) and FINEP-Pluricana Project.

\section{Availability of data and materials}

Not applicable.

\section{Declarations}

\section{Ethics approval and consent to participate}

This manuscript is an original paper and has not been published in other journals. The authors agreed to keep the copyright rule.

\section{Consent for publication}

The authors agreed to the publication of the manuscript in this journal.

\section{Competing interests}

The authors declare that they have no competing interests.

\section{Author details}

'Núcleo de Desenvolvimento de Insumos Biológicos Para a Agricultura (NUDIBA), Universidade Estadual do Norte Fluminense Darcy Ribeiro, Avenida Alberto Lamego No. 2000, Rio de Janeiro, Campos dos Goytacazes CEP 28013-602, Brazil. ' Laboratório de Melhoramento Genético Vegetal (LMGV), UENF, Avenida Alberto Lamego no. 2000, Rio de Janeiro, Campos dos Goytacazes CEP28013-602, Brazil. ${ }^{3}$ Escola Superior de Agricultura Luiz de Queiroz (ESALQ), Universidade de São Paulo (USP), Piracicaba São Paulo, Brazil. ${ }^{4}$ Centro Interdipartimentale di Ricerca CERMANU, Università di Napoli Federico II, Via Università 100, 80055 Portici, Italy.

Received: 17 May 2021 Accepted: 12 July 2021

Published online: 17 August 2021

\section{References}

1. Olivares FL, Busato JG, De Paula AM, Lima LS, Aguiar NO, Canellas LP. Plant growth promoting bacteria and humic substances: crop promotion and mechanisms of action. Chem Biol Technol Agric. 2017;4:30. https://doi. org/10.1186/s40538-017-0112-x.
2. van Oosten MJ, Pepe O, de Pascale S, Silletti S, Maggio A. The role of biostimulants and bioeffectors as alleviators of abiotic stress in crop plants. Chem Biol Technol Agric. 2017;4:5. https://doi.org/10.1186/ s40538-017-0089-5.

3. Choudhary DK, Prakash A, Johri BN. Induced systemic resistance (ISR) in plants: mechanism of action. Indian J Microbiol. 2007;47:289-97. https:// doi.org/10.1007/s12088-007-0054-2.

4. Garcia-Mina JM, Jordana R, Aguirreolea J, Hernandez MA. The effect of a special organic amendment on the development of pepper plants cultivated in a soil infested with Verticillium dahliae. In: Rodriguez-Barrueco C, editor. Fertilizers and environment, vol. 66. Dordrecht: Springer; 1996. p. 301-3.

5. Moliszewska E, Pisarek I. Influence of humic substances on the growth of two phytopathogenic soil fungi. Environm Inter. 1996;22:579-84. https:// doi.org/10.1016/0160-4120(96)00048-7.

6. Yigit F, Dikilitas M. Effect of humic acid applications on the root-rot diseases caused by Fusarium spp. on tomato plants. Plant Pathol J. 2008:7:179-82. https://doi.org/10.3923/ppj.2008.179.182.

7. Zhang S, Raza W, Yang X, et al. Control of Fusarium wilt disease of cucumber plants with the application of a bioorganic fertilizer. Biol Fertil Soils. 2008;44:1073-80. https://doi.org/10.1007/s00374-008-0296-0.

8. Loffredo E, Berloco M, Senesi N. The role of humic fractions from soil and compost in controlling the growth in vitro of phytopathogenic and antagonistic soil-borne fungi. Ecotoxicol Environm Safety. 2008;69:350-7. https://doi.org/10.1016/j.ecoenv.2007.11.005.

9. Qiu M, Zhang R, Xue R, Zhang S, Li S, Zhang N, Shen Q. Application of bio-organic fertilizer can control Fusarium wilt of cucumber plants by regulating microbial community of rhizosphere soil. Biol Fertil Soils. 2012;48:807-16. https://doi.org/10.1007/s00374-012-0675-4.

10. Afifi MMI, Ismail AM, Kamel SM, Essa TA. Humic substances: a powerful tool for controlling fusarium wilt disease and improving the growth of cucumber plants. J Plant Pathol. 2017;99:61-7. https://doi.org/10.4454/ jpp.v99i1.3810.

11. Olivares FL, Aguiar NO, Rosa RCC, Canellas LP. Substrate biofortification in combination with foliar sprays of plant growth promoting bacteria and humic substances boosts production of organic tomatoes. Sci Hort. 2015;183:100-8. https://doi.org/10.1016/j.scienta.2014.11.012.

12. Da Silva JN, Araujo TC, Ponciano NJ, Souza CLM. Diagnóstico do uso de agrotóxicos por tomaticultores do município de São José De Ubá. RJ Rev Bras Agrop Sus. 2020;10:45-50. https://doi.org/10.21206/rbas.v10i1.8579.

13. Buralli, RJ. Health effects of environmental and occupational exposure to agricultural pesticides (Thesis). São Paulo, Faculdade de Saúde Pública da Universidade de São Paulo. 2020; 193p. Portuguese. https://doi.org/10. 11606/T.6.2020.tde-20022020-082631

14. Quezado-Duval AM, Gazzoto Filho A, Leite Júnior RP, Camargo LEA. Sensibilidade a cobre, estreptomicina e oxitetraciclina em Xanthomonas spp. associadas à mancha-bacteriana do tomate para processamento industrial. Hort Bras. 2003;21:670-5. https://doi.org/10.1590/s0102-05362 003000400020.

15. Van Loon LC, Van Strien EA. The families of pathogenesis-related proteins, their activities, and comparative analysis of PR-1 type proteins. Physiol Mol Plant Pathol. 1999;55:85-97. https://doi.org/10.1006/pmpp.1999. 0213

16. Pieterse CMJ, Van Loon LC. Salicylic acid-independent plant defense pathways. Trends Plant Sci. 1999;4:52-8. https://doi.org/10.1016/S13601385(98)01364-8.

17. Van Loon LC, Bakker PAHM, Pieterse CMJ. Systemic resistance induced by rhizosphere bacteria. Annual Rev Phytopathol. 1998;36:453-83. https:// doi.org/10.1146/annurev.phyto.36.1.453.

18. Verhagen BWM, Glazebrook J, Zhu T, Chang HS, van Loon LC, Pieterse CMJ. The Transcriptome of Rhizobacteria-Induced Systemic Resistance in Arabidopsis. Molr Plant-Microbe Interact. 2004;17:895-908. https://doi. org/10.1094/MPMI.2004.17.8.895.

19. Schiavon M, Pizzeghello D, Muscolo A, Vaccaro S, Francioso O, Nardi S. High molecular size humic substances enhance phenylpropanoid metabolism in maze (Zea mays L.). J Chem Ecol. 2010;36:662-9. https:// doi.org/10.1007/s10886-010-9790-6.

20. García AC, Santos LA, de Souza ALG, Tavares OCH, Zonta E, Gomes ETM, García-Mina JM, Berbara RL. Vermicompost humic acids modulate the accumulation and metabolism of ROS in rice plants. J Plant Physiol. 2016;192:56-63. https://doi.org/10.1016/j.jplph.2016.01.008. 
21. Abbasi PA, Al-Dahmani J, Sahin F, Hoitink HAJ, Miller SA. Effect of compost amendments on disease severity and yield of tomato in conventional and organic production systems. Plant Dis. 2002;86:156-61. https://doi. org/10.1094/PDIS.2002.86.2.156.

22. Zhang W, Han DY, Dick WA, Davis KR, Hoitink HAJ. Compost and compost water extract-induced systemic acquired resistance in cucumber and Arabidopsis. Phytopathol. 1998;88:450-5. https://doi.org/10.1094/PHYTO. 1998.88.5.450.

23. Al-Dahmani JH, Abbasi PA, Miller SA, Hoitink HAJ. Suppression of bacterial spot of tomato with foliar sprays of compost extracts under greenhouse and field conditions. Plant Dis. 2003;87(8):913-9. https://doi.org/10.1094/ PDIS.2003.87.8.913.

24. Monteiro RA, Balsanelli E, Wassem R, Marin AM, Brusamarello-Santos LCC, Schmidt MA, Tadra-Sfeir MZ, Pankievicz VCS, Cruz LM, Chubatsu LS, Pedrosa FO, Souza EM. Herbaspirillum-plant interactions: microscopical, histological and molecular aspects. Plant Soil. 2012;356:175-96. https:// doi.org/10.1007/s11104-012-1125-7.

25. Döbereiner J, Baldani VLD, Baldani Jl. Como isolar e identificar bactérias diazotróficas de plantas não leguminosas. Seropédica: Embrapa Agrobiologia; 1995. p. 60.

26. Riva EM; Rodrigues R; Sudré CP; Karasawa M; Pereira MG. 2004b. Three recessive genes controlling bacterial spot resistance in pepper. In: International Pepper Conference, 17TH. Book of abstracts... Naples, USA: University of Florida. p.21.

27. Juhász ACP, Rodrigues R, Olivares FL, Araujo JSP. Interações entre Xanthomonas axonopodis pv. vesicatoria e genótipos resistentes ou suscetíveis de Capsicum annuum em tecidos foliares inoculados. Agronomia. 2006;40(1-2):27-34.

28. Mello SC, Lopes CA, Takasu A. Escala diagramática para avaliação da mancha-bacteriana do tomateiro. Fitopatol Bras. 1997;22:447-8.

29. Kyoung KS, Min JY, Dickman MB. Oxalic Acid is an elicitor of plant programmed cell death during Sclerotinia sclerotiorum disease development. MPMI. 2008;21(5):605-12. https://doi.org/10.1094/MPMI-21-5-0605.

30. Simsek-Ersahin $Y$. The use of vermicompost products to control plant diseases and pests. In: Karaca A, editor. Biology of Earthworm. Berlin: Springer; 2011. p. 191-213 (10.1007/978-3-642-14636-7_12).

31. Singh AK, Mclntyre LM, Sherman LA. Microarray analysis of the genomewide response to iron deficiency and iron reconstitution in the cyanobacterium synechocystis sp. PCC 6803. Plant Physiol. 2003;132(4):1825-39. https://doi.org/10.1104/pp.103.024018.

32. Straub D, Rothballer M, Hartmann A, Ludewig U. The genome of the endophyticbacterium $H$. frisingense GSF30 identifies diverse strategies in the Herbaspirillum genus to interact with plants. Front Microbiol. 2013:4:168.

33. Ryals JA, Neuenschwander UH, Willits MG, Molina A, Steiner HY, Hunt MD. Systemic acquired resistance. Plant Cell. 1996;8:1809-19. https://doi.org/ 10.1105/tpc.8.10.1809.

34. Canellas LP, Canellas NOA, Souza LE, Olivares FL, Piccolo A. Plant chemical priming by humic acids. Chem Biol Technol Agric. 2020. https://doi.org/ 10.1186/s40538-020-00178-4.

35. Aguiar NO, Olivares FL, Novotny EH, Canellas LP. Changes in metabolic profiling of sugarcane leaves induced by endophytic diazotrophic bacteria and humic acids. Peer J. 2018;2018(9):1-28. https://doi.org/10.7717/ peerj.5445.
36. Canellas NA, Olivares FL, Canellas LP. Metabolite fingerprints of maize and sugarcane seedlings: searching for markers after inoculation with plant growth-promoting bacteria in humic acids. Chem Biol Technol Agr. 2019;6:14. https://doi.org/10.1186/s40538-019-0153-4.

37. Ertani A, Pizzeghello D, Francioso O, Tinti A, Nardi S. Biological activity of vegetal extracts containing phenols on plant metabolism. Molecules. 2016;21:205. https://doi.org/10.3390/molecules21020205.

38. Nunes RO, Domiciano GA, Alves WS, Melo ACA, Nogueira FCS, Canellas LP, Olivares FL, Zingali RB, Soares MR. Evaluation of the effects of humic acids on maize root architecture by label-free proteomics analysis. Sci Rep. 2019;9:12019. https://doi.org/10.1038/s41598-019-48509-2.

39. Park CJ, Seo YS. Heat shock proteins: a review of the molecular chaperones for plant immunity. Plant Pathol J. 2015;31(4):323-33. https://doi. org/10.5423/PPJ.RW.08.2015.0150.

40. Cha JY, Kang SH, Ali I, Lee SC, Ji MG, Jeong SY, Shin GI, Kim MG, Jeon JR, Kim WY. Humic acid enhances heat stress tolerance via transcriptional activation of Heat-Shock Proteins in Arabidopsis. Sci Rep. 2020;10(1):15042. https://doi.org/10.1038/s41598-020-71701-8.

41. Bowler C, Camp WV, Montagu MV, Inzé D. Superoxide dismutase in plants. Crit Rev Plant Sci. 1994;13(3):199-218. https://doi.org/10.1080/ 07352689409701914.

42. Aguiar NO, Medici LO, Olivares FL, Dobbss LB, Torres-Netto A, Silva SF, Canellas LP. Metabolic profile and antioxidant responses during drought stress recovery in sugarcane treated with humic acids and endophytic diazotrophic bacteria. Ann ApplBiol. 2016;168(2):203-13. https://doi.org/ 10.1111/aab.12256.

43. De Hita D, Fuentes M, García AC, Olaetxea M, Baigorri R, Zamarreño AM, Berbara R, Garcia-Mina JM. Humic substances: a valuable agronomic tool to improving crop adaptation to saline water irrigation. Water Sci Technol Water Supply. 2019;19(6):1735-40. https://doi.org/10.2166/ws.2019.047.

44. De Hita D, Fuentes M, Fernández V, Zamarreño AM, Olaetxea M, GarcíaMina JM. Discriminating the short-term action of root and foliar application of humic acids on plant growth: emerging role of jasmonic acid. FrontPlant Sci. 2020;11:493. https://doi.org/10.3389/fpls.2020.00493.

45. Ali AYA, Ibrahim MEH, Zhou G, Nimir NEA, Jiao X, Zhu G, Lu H. Ameliorative effects of jasmonic acid and humic acid on antioxidant enzymes and salt tolerance of forage sorghum under salinity conditions. Agron J. 2019;111(6):3099-108. https://doi.org/10.2134/agronj2019.05.0347.

46. Shan C, Liang Z. Jasmonic acid regulates ascorbate and glutathione metabolism in Agropyron cristatum leaves under water stress. Plant Sci. 2010;178:130-9. https://doi.org/10.1016/j.plantsci.2009.11.002.

47. Legendre L, Rueter S, Heinstein PF, Low PS. Characterization of the oligogalacturonide-induced oxidative burst in cultured soybean (Glycine max) cells. Plant Physiol. 1993;102(1):233-40. https://doi.org/10.1104/pp. 102.1.233.

48. Baia DC, Olivares FL, Soares CP, Canellas LP. Humic acids trigger the weak acids stress response in maize seedlings. Chem Biol Technol Agri. 2020;7:31. https://doi.org/10.1186/s40538-020-00193-5.

\section{Publisher's Note}

Springer Nature remains neutral with regard to jurisdictional claims in published maps and institutional affiliations. 